\title{
REVIEW I Designed for Hi-Fi Living: The Vinyl LP in Midcentury America
}

Janet Borgerson and Jonathan Schroeder

Cambridge, MA: MIT Press, 2017

ISBN: 9780262036238 (HB)

\author{
lain Taylor \\ Birmingham City University \\ iain.taylor@bcu.ac.uk
}

The vinyl LP's resurgence as a medium for music consumption has been well documented over the past decade or so. While David Hayes (2006: 51) noted vinyl's "(re)emergence" as an "alternate format for music consumption in the digital age" as early as 2006, the so-called vinyl revival began to catch the attention of the music press around the turn of the decade and has continued unabated ever since. With this resurgence of popular interest in vinyl has come a wealth of scholarship around the vinyl record, its shifting cultural significance, and the role that it plays in a cultural landscape dominated by digital technologies. Much of this scholarship has focused on areas such as vinyl's development as a format (see Osborne 2012) record collection (see Shuker 2010 and Marshall 2016, for example) and vinyl's place within increasingly digitalized systems of music production and consumption (Bartmanski and Woodward 2015; Morris 2015).

While borne out of the authors' shared passion for record collecting and fascination with the colourful kitsch of mid-century American LPs, Borgerson and Schroeder's book is not particularly concerned with the vinyl record in-and-of itself. Although nominally taking the vinyl LP as its object of study, the form, format, and musical content of the records examined in their work is almost incidental to the wider argument made by the authors. Structured around the description and analysis of almost 150 LPs from the 1950s and 60s, the authors use examples of artefacts from their collection to paint a detailed picture of how mid-century consumer goods bridged a gap between the domestic and public spheres in American life.

As such this book is, in the words of the authors, "a reflection on design, media, visual culture and history" (xii). The book is structured around two key sites of 
conspicuous consumption for the socially aspirant mid-century American family: the home as a symbol of domesticity, style, and security; and foreign travel as an outward gesture of culture and sophistication. Chapters within these sections allow for more detailed exploration of themes which emerge out of their analysis (for example, "Modern Art and Design" and "Being at Home") or specific tourist destinations ("Hawaii" or "New York"). Through detailed and systematic exploration of the cover art of a range of records, the authors highlight the connections between the sleeve design of numerous LPs of the time and the aesthetic trends in household décor, fashion, and taste of the post-war nuclear family that dominated during this period.

The "Home" section of the book addresses the role that the LPs played in constructing and navigating the new American lifestyle of the 1950s and 60s. In the case of many of the popular titles that Borgerson and Schroeder explore - such as Columbia's Music for Gracious Living or RCA's Music for Hi-Fi Living - the musical content of the albums is presented as secondary to a deeper underlying purpose; that is, to instruct the audience in the art of tasteful consumption. Titles such as Music for a Backyard Barbeque, or Music to Paint By, act as blueprints for American families looking to navigate the changing cultural landscape of their post-war nation. As such, the authors argue, these LPs and the covers which adorn them are not simply the product of mid-century American consumerism, but in fact serve to actively produce it. They present the LPs as pedagogical in nature, informing and instructing consumers on a range of subjects from dйcor and design to dinner party menus. Through a combination of highly stylized sleeve design depicting modernist

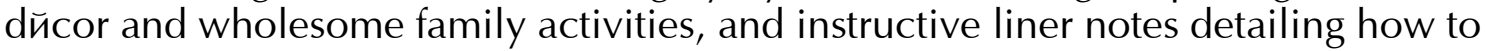
achieve the effortless style and domestic bliss depicted, the companies and sponsors producing these LPs actively sought to shape burgeoning consumer trends.

Whereas the albums explored in the "Home" section act as style guides designed to guide post-war consumers in decorating their homes, hosting barbeques, or throwing cocktail parties, those addressed in "Away" function as travel brochures, promoting glamourous visions of luxury cruises, elegant city breaks in London or Paris, or salsa dancing at the Habana Hilton. Sponsored by airlines such as Pan Am and Sabena, titles such as RCA Victor's Holiday Abroad in... series presented foreign travel as a core tenet of American middle-class-ness: the perfect source of anecdotes to discuss at your next dinner party or barbeque, sound tracked (of course) by the requisite LP from the aforementioned series.

This publication offers a thoughtful and compelling perspective on the vinyl record as material culture, and a reflection upon how the enduring materiality of the records explored acts as a historical document of the post-war American imagination. There is a palpable sense of the authors' enthusiasm for the artefacts discussed, but that enthusiasm is balanced against an underlying criticality about their subject matter and presented as part of a detailed account of design, culture, and politics in mid-century America. While the lack of a concluding chapter feels like a missed opportunity to draw together the recurring themes and strands of thought which run throughout, the book nonetheless acts as a timely reminder that discussions of materiality in relation to music formats cannot exist outside of a wider socio-cultural context.

\section{References}

Bartmanski, D. and Woodward, I. 2015. Vinyl: The Analogue Record in the Digital Age. London: Bloomsbury. 
Hayes, D. 2006. "Take Those Old Records off the Shelf": Youth and Music Consumption in the Postmodern Age. Popular Music and Society 29 (1): 51 68.

Marshall, L. 2016. W(h)ither Now? Music Collecting in the Age of the Cloud. In L. Marshall and D. Laing Eds. Popular Music Matters: Essays in Honour of Simon Frith. London and New York: Routledge: 61-74.

Morris, J.W. 2015. Selling Digital Music, Formatting Culture. Oakland, CA: University of California Press.

Osborne, R. 2012. Vinyl: A History of the Analogue Record. Aldershot: Ashgate Shuker, R. 2010. Wax Trash and Vinyl Treasures: Record Collecting as a Social Practice. Surrey: Ashgate. 